Published: ILR Review, Vo52, no. 1, 1998

\title{
Industrial Relations System Transformation
}

\begin{abstract}
$\underline{\text { Abstract }}$
This paper analyzes the concept of "transformation” that many allege has occurred recently in a wide variety of national industrial relations systems. After a summary of the debate, with particular reference to the contentious case of Germany, we attempt to develop a definition of industrial relations system transformation on the basis of biological analogies and, in particular, the "punctuated equilibrium" theory. We examine the cases of the United States, Sweden, South Africa, and New Zealand, and conclude that the application of the biological frameworks raises a set of fundamental questions that must be addressed in order for the debate over the existence of industrial relations transformation to move forward.
\end{abstract}

\section{Christopher L. Erickson and Sarosh Kuruvilla}

May 1998

* The authors are associate professor in the Human Resources and Organizational Behavior area of the UCLA Anderson Graduate School of Management and associate professor in the Collective Bargaining, Labor Law, and Labor History department and International and Comparative Industrial Relations department of the School of Industrial and Labor Relations at Cornell University, respectively. We thank Torben Andersen, Jack Fiorito, Stephen Frenkel, Connie J.G. Gersick, Miriam Golden, Sanford Jacoby, Harry Katz, Michael Piore, Anil Verma, Michael Wallerstein, and Niels Westergaard-Nielsen for their comments on earlier drafts of this paper, as well as seminar participants at the Fourth Bargaining Group conference, Aarhus School of Business, Michigan State University, Seoul National University, Cornell, and UCLA. Partial funding was provided by a research grant from the UCLA Academic Senate. 


\section{Introduction}

In recent years, a debate has opened regarding “transformations” of industrial relations systems in a variety of countries. On the one hand, there is a growing body of research that argues for the existence of such widespread transformations. What is remarkable is that these alleged transformations have occurred during the last two decades all over the world. For example, several authors have argued that there have been fundamental changes in industrial relations in various OECD countries (Locke, Kochan, and Piore (1995); Katz (1993), Swenson(1989); Kochan, Katz, and McKersie (1986); Streeck(1988); Frenkel (1988); Bray and Hayworth(1993); Armingeon (1994)). Some authors have also noted transformations in developing nations in Asia, Africa, and Latin America (Kuruvilla (1996), Webster(1997), Cook (1996)), and as well there is a body of research that examines transformations in industrial relations in the former Soviet block (Jurgens, Klinzig, and Turner(1993), Jones (1995)).

Despite this body of research arguing for widespread transformation, there is also disagreement about whether transformation is in fact occurring. For example, in studies of several of the same advanced European countries examined by Katz, Crouch(1993) and Hyman(1994) argued that there has been essentially no transformation in industrial relations in these countries. And, Golden, Wallerstein, and Lange (1997) analyzed data on industrial relations in 8 Northern and Central European countries over the period 1950-90, concluding that there has not been a widespread transformation over the last two decades. Finally, Dunlop(1993) categorically rejects the arguments regarding recent industrial relations transformation in the 
United States and, by extension, in many other countries where transformations have been claimed.

Thus, there appears to be substantial disagreement about the extent of recent transformation of industrial relations systems around the world. The debate raises several basic questions about the developments in the various national industrial relations systems. Are the changes in industrial relations seen in the 1980s and 1990s really fundamental (do they constitute transformation)? And, more generally, how might we distinguish “transformation” from "nonfundamental change,” and are there different types of industrial relations system “transformations”?

Before this debate can be resolved and these questions adequately addressed, however, it is necessary to consider whether the various authors are addressing the same concept; is there even a common definition of "transformation?" Our answer to this question, based on our reading of the literature, is an unqualified “NO!” We also find that, absent a common definition and agreement on what constitutes transformation, different authors have used widely different types of evidence to support their transformation theses.

Our purposes in this paper are fourfold. First, we summarize the existing definitions of and arguments regarding recent industrial relations transformation. Second, we briefly analyze the manner in which several of these definitions have been applied to a particularly contentious and well-documented country case: Germany; the analysis of this case helps to sharpen our understanding of the disagreement. Next, we provide an argument of our own for the meaning of the distinctions between "transformation” and "non-fundamental change” and between “incremental” and “discontinuous” transformations, based on analogies from evolutionary biology 
and especially the "punctuated equilibrium" theory of social change. We end by discussing the questions for future research raised by the application of these analogies and by briefly applying the analogies to industrial relations change in several countries, with a particular emphasis on the developments in industrial relations in the twentieth century in the United States.

\section{Definitions of Industrial Relations “Transformation"}

An examination of the literature on the recent development of industrial relations systems indicates a lack of consensus on what constitutes "transformation,” or fundamental change. The influential book The Transformation of American Industrial Relations (Kochan, Katz and McKersie(1986)) has formed the basis for much of the debate, if not a common structure or definition for understanding the concept. Kochan, Katz, and McKersie considered the level where bargaining takes place and who makes the key strategic decisions, and argued that decentralization in bargaining, management's increased autonomy, and the switch to a bundle of workplace practices that included teams, contingent pay, employee participation, training, and employment security amounted to a transformation in the United States.

In another examination of recent industrial relations change, a cross-national analysis of studies of collective bargaining, Katz(1993) found that a common feature of industrial relations change in Sweden, Australia, the former West Germany, Italy, the United Kingdom, and the United States was significant employer-initiated decentralization of bargaining. Locke, Kochan, and Piore (1995) emphasized four common factors in the transformations of the United States, United Kingdom, Australia, Spain, Italy, France, Germany, Sweden, Norway, Japan, and Canada: an enterprise focus (as the locus of human resources and industrial relations decision making and 
strategy), increased flexibility (in how work is organized and labor is deployed), the growing importance of skill development, and union membership declines. Armingeon (1994) emphasized changes in industrial relations legislation in order to claim that there has been transformation in 21 European countries. Kuruvilla (1996) focused on overall national industrial relations and human resource management policies in selected Asian countries, and suggested that a change in national IR/HR policy goals of stability to that of workplace flexibility is evidence that some Asian systems are transforming.

On the anti-transformation side, Golden, Wallerstein, and Lange (1997) examined quantifiable indicators of union strength and bargaining decentralization over the past 40 years: union density and coverage rates, union concentration and monopoly, the statutory authority exercised by both central union and central employer organizations, and the centralization of wage bargaining. ${ }^{1}$ On the basis of their analysis of these indicators, they concluded that industrial relations and collective bargaining have remained essentially stable in most of the 8 Northern and Central European countries in their sample, and that only Sweden shows evidence of a substantial recent decentralization of collective bargaining.

Crouch(1993) considered the stability of formal institutional mechanisms, such as laws regarding co-determination, in concluding that we have not seen major change in most European industrial relations systems since the era of state formation, when the basic and stable "social bargain” was negotiated in each of these countries. He argued that national industrial relations systems in Europe have been essentially stable over the twentieth century, that situations of

\footnotetext{
${ }^{1}$ In a related study, Golden and Wallerstein (1996) examined these indicators as well as the extent of autonomy of shopfloor union organizations, the extent of confederal control of wage bargaining, and the extent to which national industrial unions control wage setting in 16 OECD countries over the same period, reaching substantially similar conclusions.
} 
change in style and structure (due to imitation) are rare, and that differences in industrial relations systems, particularly the presence or absence of neocorporatist industrial relations structures, are stable and "reflect deeper historical differences in the occupancy of political space” (pp. 349-50). ${ }^{2}$ Hyman(1994) analyzed the dimensions of change in management initiative, decline of unionism, deregulation of labor markets, and decline of national systems in the twelve EC and seven EFTA countries (as of the time of his writing). On this basis he largely rejected the hypotheses of recent transformation and convergence toward a new post-Fordist model.

Dunlop(1993) argued in regard to the debate over the transformation of the United States industrial relations system that "Most of the developments of the 1980s in my view represented adaptations to the changing demographic, market, technological, and political environment, and to the relations among the actors, inducing changes in the contours of the system and some rules; but they did not fundamentally transform the United States industrial relations system” (p. 21). He suggests that a true transformation requires a radical change in the external constraints influencing the system, as has been occurring in the political/economic system of the former Soviet Union. He also argues that “The Transformation of American Industrial Relations cannot be a general theory of industrial relations ... for it is not directly applicable to other countries that are advanced or are developing in the third world” (p. 20), apparently due to his perception of the institutional specificity of Kochan, Katz and McKersie’s argument.

Others have examined industrial relations outcomes such as wage dispersion and wage

\footnotetext{
${ }^{2}$ Nevertheless, Crouch does give some credence to arguments that neo-corporatist institutions, fundamentally dependent on political and (usually) national structures, are being eroded (or at least being made redundant) by the growing autonomy of the company in industrial relations, that "while neo-corporatism may have been useful for the macro-level stabilization crises of the 1970s, it is less equipped for the detailed, company-by-company restructuring characteristic of the contemporary economy" (p. 343). He also concludes that "Any new lease of life for neocorporatist institutions will depend on either the construction of more broadly-based labor coalitions, or on the
} 
"drift" in particular. While this approach holds the promise of providing meaningful tests of the hypotheses regarding recent decentralization of responsibility, decision-making, and industrial relations policy-making, these studies have found mixed evidence of increased variation in industrial relations outcomes in various countries (e.g. the volume by Freeman and Katz(1995)).

Clearly, then, the authors in this debate examine different aspects of the hypothesized industrial relations "transformation." Some examine formal institutional structure such as legislation or union density and coverage, while others examine informal or process-oriented indicators such as the extent of employer versus union initiative in bringing about change or the level of the industrial relations system which constitutes the "locus" of decision making and strategy. Still others examine quantifiable outcomes of the industrial relations process, such as wage dispersion. Some focus on wage setting, while others examine a broader range of aspects of the employment relationship. Given these differences, summarized in Table 1, it should hardly be surprising that the various authors can reach such different conclusions.

\section{--- INSERT TABLE 1 ABOUT HERE ---}

The differences in definition and approach taken by the various authors thus clouds the basic underlying issue: is there a fundamental change (or "transformation") in structure and practice taking place in industrial relations systems world-wide? This debate raises the question of whether "decentralization" amounts to "transformation.” And, if it does, can it be meaningfully quantified? And, if it can, why do Golden, Wallerstein, and Lange (1997) in particular fail to find 
"hard" evidence of significant decentralization in many countries where others have drawn the opposite conclusion based on more qualitative evidence? Alternatively, should "transformation" be defined in terms of legislation, formal institutional mechanisms, government economic strategies, or some combination thereof? Or, should it be defined not in terms of industrial relations system structure and process, but rather in terms of system outcomes such as the diffusion of innovative workplace and compensation practices or wage drift and dispersion? This lack of clarity and agreement on fundamentals is apparent in the differing analyses of a widelystudied country case: Germany; we turn next to a brief summary of the arguments regarding transformation (or lack thereof) of the German industrial relations system in order to examine the debate in more concrete terms.

\section{An Illustrative Country Case: Germany}

The arguments for the existence of a transformation of the German industrial relations system generally boil down to the proposition that the locus of collective bargaining and worker influence more generally have significantly decentralized from the industry or regional levels to the establishment or enterprise level, that the enhanced role of the works councils in local bargaining amounts to a significant enough shift in the process and outcomes of negotiations to constitute a "transformation.”3 This view is perhaps most explicitly stated by Streeck (1988):

While central features of the West German system of collective bargaining have remained in place - in particular, the practice of interconnected industry-wide agreements and the 'strike monopoly' of industrial unions, making for relatively low wage drift and low wage differentials between firms, industries, and regions - there

\footnotetext{
in the balance of systems towards the level of the company” (p. 350).

${ }^{3}$ Note that the existing literature mostly abstracts from the issues raised by the unification of the former East Germany with the FRG, which occurred after the alleged transformation had begun.
} 
have also been significant changes. However, since these changes have proceeded gradually and along the lines of evolutionary tendencies that have been present for at least two decades, they are not always obvious. Nevertheless, in effect they add up to a cumulative transformation of the system, in the course of which the centre of gravity of collective bargaining is shifted from the industrial to the establishment and enterprise level, where workers are not represented directly by trade unions but by elected works councils. (pp. 22-23). ${ }^{4}$

Similarly, Katz (1993), in his review of work on decentralization of bargaining in several countries, concluded that

In Germany ... a number of analysts have observed a significant shift toward decentralization in the importance and amount of negotiations that occur inside the works councils at the plant level ... The productivity coalitions being negotiated at the plant and workshop level typically involve changes in work organization and team work ... Although the formal structure of collective bargaining has not changed, a more decentralized bargaining structure has resulted from changes in the sectoral collective bargaining agreements. (p. 8).

However, Crouch (1993) and Golden, Wallerstein, and Lange (1997) reach very different conclusions. Crouch concluded that an enduring social contract has led to "organized industrial politics” in Germany over the past 100 years; he places Germany firmly in the class of “facilitating” corporatist systems, and argues for inherent stability, even across the pre- and postwar periods, but certainly during recent decades.

Golden, Wallerstein, and Lange argue for stability of the German system on the basis of their quantitative measures of the structures of collective bargaining (particularly wage setting)

\footnotetext{
${ }^{4}$ The same basic argument has been advanced by Koch (1995): "Works councils are a central feature of the German industrial relations system. As German unification has progressed their role has become increasingly central to the collective bargaining process... Evidence suggests that the transformation process in Germany has allowed works councils to evolve into flexible and responsive institutions" (abstract).

Baethge and Wolf (1995) argue that "During the 1980s a gradual transition took place as the bargaining process shifted from the industry to the firm level ... Increasingly works councils, rather than the unions, are assuming the primary role in interest representation ...” (p. 231). "Just because the formal structures of the German model have not yet collapsed, we should not obscure the important changes that have taken place in recent years. These social developments raise questions about the assumptions of how the society ought to function ...” (p. 250).
} 
and the industrial relations system. Briefly, they found that union density and coverage, interconfederal union concentration, formal statutory authority of national metalworking workers' and employers' associations (the DGB and BDA), and confederal and government involvement in private-sector wage bargaining have been basically stable. In a related study, Golden and Wallerstein (1996), on the key question of "autonomy of the shopfloor,” examined the dimensions of "(1) whether shopfloor representatives are required to be union members; (2) whether shopfloor representatives can be dismissed or replaced by higher levels of union organizations; (3) whether shopfloor representatives have to negotiate enterprise or plant level agreements and (4) whether shopfloor representatives have their own strike funds or automatically are entitled to them in the event of industrial conflicts” (p. 56). On this basis, they also argue for a lack of significant change in German shopfloor industrial relations.

Finally, in a study of the outcomes of the wage negotiations process, Abraham and Houseman (1995) studied overall earnings inequality and earnings differentials across skill, education, and age groups over the 1970s and 1980s in the former West Germany. Contrary to prior studies based on less comprehensive data sets (e.g. Davis (1992)), they found no evidence of growing earnings inequality or widening earnings differentials along these dimensions, suggesting a lack of decentralization in outcomes.

In this case, the contrast between the conclusions of those who analyze formal institutional structures as compared to those who analyze informal process is particularly stark. Works councils have no more formal authority than previously, and on this basis (as well as on the basis of other quantifiable indicators of structure), Golden, Wallerstein, and Lange conclude that the German system has not transformed. On the other hand, on the basis of less quantifiable 
indicators, others conclude that there has been a substantial shift in the "center of gravity" of collective bargaining , as evidenced in the new substance of the sectoral agreements, particularly as regards productivity coalitions and the allocation of working time. ${ }^{5}$ In a certain sense, the debate seems to be between the question of what works councils CAN do (which hasn't changed much) as against what they in fact are doing (which seems to have changed a great deal). An important question, then, is to what extent do significant changes in workplace practice and the locus of emphasis of strategy and competitiveness amount to a transformation of an industrial relations system? Should such changes, if truly amounting to a transformation, show up in quantifiable outcomes? And, which outcomes and with how much of a time lag? Most basically, how can we measure the "significance" of a decentralization of the substance of bargaining and interest representation ${ }^{6}$

\section{The Distinctions between (1) "Non-Fundamental Change” and "Transformation" and (2) "Incremental” and "Discontinuous" Transformation : Some Theoretical Structure based on Evolutionary Biology.}

Given the intense debate, and the confusion caused by definitional differences, we attempt to bring some clarity to the issue by distinguishing between "non-fundamental change" and "transformation" and between "incremental” and "discontinuous” transformations. In order to provide a framework for understanding these distinctions, we utilize the evolutionary biology versus punctuated equilibrium debate (Darwin (1859), Gould (1991)) in the natural sciences as a

\footnotetext{
${ }^{5}$ Turner (1992) provides a comprehensive analysis of the new roles of the works councils.

${ }^{6}$ Note that recent events suggest that the decentralization and emphasis on flexibility may now start showing up in wage outcomes: on June 4, 1997, the chemical workers' unions agreed to a contract allowing companies to
} 
metaphor, postulating that each model has some relevance for different types of social system change. In other words, as we will discuss below, we do not view evolution and punctuated equilibrium as either/or descriptors of any and all industrial relations system change (although some may choose to make such an argument), but rather as two imperfect metaphors for different types of change in industrial relations systems.

This framework essentially allows us to describe the process of change in a given industrial relations system and to evaluate the extent of "transformation," and its application could potentially help researchers to identify the critical differences across nations that make systems adaptive or nonadaptive. One advantage of using this framework is that it is largely "culture free," i.e. not clouded by vagaries of national culture, an essential requirement for cross national explanation. Again, we will attempt to sharpen the distinction between transformation and nonfundamental change and to describe two types of transformation through the use of the biological analogies; we first focus on clarifying the concept of evolutionary change or adaptation.

An important characteristic of the concept of evolution is Darwin's principle of functional change in structural continuity. The problem this principle attempts to address is this. We can understand how fully developed structures work, such as the various parts of the German industrial relations and economic systems. Yet, how do we understand how these complex systems evolved slowly to their current state? An analogy in natural history, described in Gould(1991), is that we know what a wing is. Yet, birds did not always have wings. The problem then is how can natural selection explain the incipient stages of structures that can only be used in more elaborate form? In other words, birds can fly with wings, but no bird can fly with $2 \%$ of a 
wing. The wing is a structure that can only be used in its most elaborated form ( $100 \%$ of the wing, but not in any lesser form). The principle of functional change in structural continuity simply states that it is possible for gradual conversion to occur from one function to another. This idea of functional shift has been used to explain why birds have wings, though birds descended from reptiles, who now don't have wings. The hypothesis is that wings originally performed the function of thermoregulation, since they were analogous to reptilian scales.

In industrial relations terms, the implication is that a fundamental change of function in any one institution can still be an evolutionary (or incremental) and not a revolutionary (or discontinuous) change. For example, the National Wages Council in Singapore was designed to keep wage increases uniform throughout the economy, and competitive with regard to other Asian nations, at a time when Singapore's economic development strategy was based on export oriented industrialization based on low labor costs (Kuruvilla (1996)). Today, however, the National Wages Council emphasizes the need for non-uniform wage increases, and its once powerful presence in the economy has faded somewhat with the increasing decentralization and variance in pay across the private sector. The NWC thus is performing a very different function compared to what it was designed to do, and its relative decline in recent years has been suggested to be a fundamental change. But, using the functional change in structural continuity metaphor, this could well be indicative of another evolutionary step in Singapore's industrial relations system, i.e. it is consistent with an evolutionary point of view, suggesting adaptability.

A second implication of natural selection is that there is a significant effect of contingency and incumbency in evolution; i.e., Gould (1991) calls a historical event contingent when it occurs

exemptions from industry-wide work rules (New York Times, 6/5/97). 
as a result of a long string of unpredictable consequences rather than as a necessary outcome of natural laws. Such contingent events depend crucially on choices made in the distant past. Minor changes made early in the game can nudge a process onto a new pathway. Small and unimportant changes, unrelated to the working integrity of a complex creature or organization, may often lead a system into a new direction. Such a consequence, if viewed from the perspective of the current outcome, may seem fundamentally different compared to the old system, yet it would not, in evolutionary theory terms, be classified as revolutionary or discontinuous given its historical links to small decisions in the past. For example it can be argued that the efforts of Singapore and Malaysia to introduce "house" unions were small changes, but that has resulted in fundamentally altering labor-management relations in those countries over time. Similarly, in the Philippines, the Aquino government's encouragement of voluntary arbitration and joint labor management councils, which constituted small changes in Philippine industrial relations policy at the time, have arguably led to debates calling for a fundamental redesigning of the entire Philippine industrial relations system (Kuruvilla (1996)).

These considerations suggest that gradual or "evolutionary” change can result in major changes in structures, such as institutions, with the passage of time and the development of practice. ${ }^{7}$ They also suggest that the extent and nature of system "transformation” cannot be evaluated by considering the changes in particular institutions (such as bargaining structure) in isolation, or without consideration of the process driving these changes. Thus, the analogy with

\footnotetext{
${ }^{7}$ At first glance, we might easily conclude that the existence of human agency seriously limits the applicability of these biological analogies. After all, a lizard certainly does not consciously attempt to become a bird. How about entire social systems, such as an industrial relations system, though? Even if a single "actor" or "group of actors" attempts to transform a complex social system, is there any reason to expect that the intended consequences will result? The particular difficulties involved in designing structures and policies so as to achieve intended results, as well as the compromise nature of much of (democratic) policymaking and just the extreme complexity of most
} 
evolutionary biology may help to provide researchers with a framework that allows nuanced judgments as to whether a change is transformatory , and if so whether it is smoothly evolutionary or discontinuous. We next attempt to develop these ideas further by appealing to another biological analogy.

An alternative biological theory to continuously smooth evolution is punctuated equilibrium theory, used primarily in natural history (Elderedge and Gould 1972), but also used in a variety of different contexts, such as in the study of the history of science (Kuhn 1962), industrial transformation (Abernathy and Utterback 1982), organizations (Miller and Friesan 1984), group development (Gersick 1988), adult development (Levinson 1978), and technology (Piore and Sabel 1984). It has also been applied in studies of aspects of industrial relations change in earlier historical periods, as in Collier and Collier's (1991) analysis of Latin American state strategies of dealing with the labor movement, and Gordon, Edwards, and Reich’s (1982) analysis of the transformations of labor over the history of the United States. Our application of the framework to the question of recent industrial relations system change, we argue, provides a basis for an understanding of industrial relations system transformation in a variety of national contexts where gradual adaptation of existing structures does not occur. This analogy helps us to clarify the definition of "discontinuous" industrial relations transformation, and the definitional arguments regarding punctuated equilibria also provide a framework for evaluating the general concept of transformation, whether incremental or discontinuous.

The basic notion behind applying the "punctuated equilibrium" theory to social development is that a social system - such as an industrial relations system - undergoes periods of

social systems suggests to us that these biological analogies might have more applicability at the level of social 
apparent stability with only gradual and non-fundamental change punctuated by periods of rapid change when the basic assumptions and principles underlying that system come under question. In their seminal work on organizational ecology, Hannan and Freeman(1989) describe the generic form of the "punctuated equilibrium" view of change as follows: "most of evolutionary history shows little change except for brief periods or punctuations in which there is rapid speciation and great increases in diversity.... the punctuations are due to combinations of environmental circumstances that open new niches into which new forms ... can radiate"(p. 38).

Gersick(1991), who describes the generic form of the theory as "an alternation between long periods when stable infrastructures permit only incremental adaptations, and brief periods of revolutionary upheaval" (p. 10), argues that the three main components of the punctuated equilibrium paradigm are deep structure, equilibrium periods, and revolutionary periods. She further posits that "the first of these, deep structure, is the most critical for understanding the models, and it is the hardest concept to define and communicate" (p. 13); she defines it as "a network of fundamental, interdependent 'choices,' of the basic configuration into which a system's units are organized, and the activities that maintain both this configuration and the system's resource exchange with the environment. Deep structure in human systems is largely implicit" (p. 15). Using Gersick's terminology, then, a central question regarding whether an industrial relations system change is "transformatory" is the extent to which change in "deep structure" comes under serious consideration.

In the realm of social system change, we also posit that the "punctuated equilibrium" theory bears a close relationship to the French "regulation" framework (Boyer(1990)), postulating 
in its essence that once regulatory mechanisms consistent with a given environment appear and develop, they both stabilize and thrive on the stability of that environment, until the regulatory system loses its viability and massive experimentation eventually leads to the development of a new system both internally consistent and viable in the new environment. In this realm of macro social system change, the theory also has clear antecedents within Marxian dialectical materialism: the idea of a system intensifying its contradictions and following its own inherent logic until the system collapses under the weight of that logic (Hofstader (1945)). As, for example, in Piore and Sabel's (1984) analysis of technological choice in economic systems, in the more general version of the theory periods of revolutionary change are brought about by a complex interplay of factors internal to the system in conjunction with external influences. Clearly, a basic question involves the extent to which factors internal to a given system (such as demographics), factors external to a given system (such as the alleged recent "globalization" of the world economy), or a complex interplay of the two tend to drive system change.

In addition, some variants of the theory imply that during periods of crisis, the basic parameters of the system are "up for grabs," or particularly contingent and unpredictable (Piore and Sabel(1984)). The system could emerge from its period of revolutionary change to go in many possible and radically different directions, depending on such things as history, politics, natural endowments, and the force of certain personalities. David(1985) refers to this phenomenon as "path dependence." However, regardless of how contingent or determined the changes are, once the new "deep structure" underlying the emergent system has been established, it forms the basis for a period of stability.

As Hannan and Freeman and Gersick suggest, periods of revolutionary change are 
characterized by the following :

a) During such periods the fundamental assumptions and principles underlying the system come under question. In other words, there is a re-consideration of what Gersick calls the "deep structure.”

b) The change is rapid, and between periods of rapid change, there are longer periods of stability.

c) These are periods during which there is great experimentation and increases in speciation and diversity, as various new forms are experimented with before one dominant form takes root.

We posit that those general questions are the appropriate place to start when considering the extent to which a "transformation" has occurred in a given industrial relations system. Is there a serious re-consideration of the "deep structure” of the basic principles of the industrial relations system? Is change in structure and practice occurring rapidly relative to the past? Is there widespread experimentation and "speciation" occurring in such realms as workplace practices? In our view, the first question regarding reconsideration of deep structure is the common element determining transformation (as opposed to "non-fundamental change") in general, while the second and third questions are relevant to the distinction between the two types of transformation, discontinuous and incremental. We will return to these distinctions below.

\section{Broad Implications for Future Research into Industrial Relations System Change}

There are several important implications for future research into industrial relations system change that can be drawn from the biological analogies presented above. The analogies suggest that the essence of "transformation" of a system is the extent to which "deep structure," or the network of fundamental, interdependent choices that determine the basic configuration into which 
an industrial relations system’s units are organized, has been reconsidered. While much of the previous literature has examined a variety of outcomes ${ }^{8}$ without a clear focus on the changes in underlying structures that truly distinguish transformation from non-transformative change, these analogies suggest that it would be most fruitful to focus on those underlying structures. The first, and perhaps most difficult task is to identify the key components of the "deep structure” of a given social system, and whether reconsideration of deep structure has occurred; if so, the biological analogies would suggest that the change be labeled as a "transformation.” In other words, a key task for future research is to understand what is the composition of key underlying structures, as well as the dynamics of these structures that make some changes transformative in nature, whether the change is incremental or discontinuous

Second, researchers should attempt to distinguish between “incremental” (or adaptive) and “discontinuous” (or punctuated equilibrium) transformations and be clear as to which type of transformation is occurring in each particular case. Previous research has mostly neglected this distinction. Because both types of transformations involve reconsideration of “deep structure,” or basic underlying assumptions, the two types of "transformation" do not necessarily differ in outcomes per se, but rather in the process of change. We have argued here that the two factors suggesting discontinuity, or a punctuation, are the speed of change relative to the past history of a given system, and the occurrence of marked increases of speciation and diversity, or experimentation with new forms.

A related question for future research is whether one type of transformation is more common than the other. Can the various national industrial relations systems be categorized in

\footnotetext{
${ }^{8}$ As noted above in the review of studies on Germany, the outcomes examined include such things as bargaining
} 
terms of the type of recent change, incremental or discontinuous? And, do industrial relations systems generally tend to undergo significant change in brief punctuations, or do they tend to be more adaptive? An extreme hypothesis to investigate here would be whether industrial relations change (and perhaps social system change more generally) is necessarily discontinuous; i.e. whether "punctuated equilibrium" is in fact synonymous with "transformation" in this context. Can a complex social system in fact gradually evolve into something very different, in the process calling into question and perhaps changing underlying basic assumptions? As we will discuss below, in our view, the diversity in experience of national industrial relations systems clearly suggests the possibility that some industrial relations systems are more adaptive than others, and that fundamental transformation of deep structure does not generically require punctuated change, but we recognize that this is a controversial and unresolved question.

\section{Examples of Industrial Relations Transformations in Terms of the Biological}

\section{Analogies}

As noted above, the biological analogies suggest two types of "transformations": incremental or adaptive, and discontinuous or punctuated, with both involving reconsideration of deep structure. We will mainly provide recent examples of punctuated equilibria in industrial relations systems in this section in order to illustrate and emphasize the most radical and controversial of the biological analogies, but we want to emphasize that, in our view, "incremental" or "adaptive" transformations are also possible; we will return to this point at the end of this section, when we briefly re-consider the German case. 
In the realm of industrial relations, the punctuated equilibrium argument is, briefly, as follows. Industrial relations systems get set at certain historical moments and remain so without major modification for extended periods of time (e.g. Katz, Kuruvilla, and Turner (1994)). Thus, although industrial relations systems are dynamic, and continuously evolve and change, there are key historical junctures or moments of transition when the systems undergo rapid change, “deep structure” (such as the basic assumptions regarding the nature of the employment relationship) comes under serious consideration, and there is a great deal of experimentation in industrial relations policy and practice. Between such critical junctures, the systems typically undergo relatively minor modifications (or, in other terms, they evolve). The key historical junctures represent punctuations or “discontinuous transformations.”

Relatively uncontroversial examples of a punctuations in industrial relations systems do exist. For example, it is widely accepted that the Swedish system, which evidenced a steady evolution into the famous Swedish model since 1938, underwent a fundamental transformation in the late 1980s and early 1990s. The Swedish collective bargaining model was based on the need for a delicate balance between representation and incomes policy mediation (Ryner (1994)). The centralized wage bargaining system resulted in moderate wage increases and relatively low strike rates, the government complemented the centralized bargaining system by following an expansionary fiscal policy and an active labor market policy, and trade unions used the system to implement their solidaristic wage policies that were focused on reducing inequality among the labor force (Swenson (1989)).

In the middle of the 1980s, this centralized bargaining system began to be questioned by many employers, given differences in the economic environments facing different industries. They 
pushed unsuccessfully for more decentralization, and by the latter half of the 1980s, the tensions between the $\mathrm{LO}$ and the SAF and within the different industrial unions and employers in these federations could not be contained any longer. Thus the bargaining rounds of 1986 and 1988 were characterized, as Katz (1993) suggests, by a move away from centralization (as several employers withdrew from the system), a substantial increase in enterprise-level bargaining, and a much greater intensity and depth to local bargaining over non wage issues. Wage policies of firms began to emphasize productivity, profit sharing, and contingent pay systems, suggestive of a shift towards a market orientation.

The bargaining rounds in the 1990s have been characterized by a period of great experimentation in Sweden (Elvander, 1997). While some parties continue to push for further decentralization, there have also been efforts to create new collective bargaining norms. For example, the 1989-1990 round represented a return to centralized bargaining for most of Sweden, excepting the engineering industry. The 1990 and 1992 bargaining rounds were characterized by several different experiments and proposals, such as a wage freeze by the government (to provide stability given inflation), which was vociferously opposed by all unions. Finally the parties accepted a norm suggested by a group of chief negotiators (the Rehnberg group). But given difficulties in implementation in different industries, the Rehnberg group also functioned as mediators; thus, this was a period of mediated centralization with some further pressures for decentralization.

The 1993 round represented continued experimentation with mediated centralization, with members of the Rehnberg group functioning as conciliators for agreements which then set the pattern for the industry, but local level decentralization also continued apace. The bargaining 
round of 1995 was characterized by even less centralization via the mediation of the Rehnberg group and more individualized local agreements, although the Rehnberg group proposed a "Europe norm” (primarily to make the transition into the EEC monetary union smoother) which was adopted to some extent in the private sector. Differentiation increased further, however, with much sharper divisions between the private and public sectors; the latter experienced far more decentralization in terms of the proportion of increases that were locally determined.

Thus, there has been a lot of experimentation (or, in terms of the punctuated equilibrium theory, an increase in speciation and diversity) in the Swedish system, as the parties try to reach a new equilibrium. Each bargaining round has been qualitatively different from the previous one, and in each round the degree of decentralization has generally increased. Most all observers label the recent events as a "transformation" of Swedish industrial relations.

Two other relatively uncontroversial examples of punctuations in industrial relations systems have occurred recently in New Zealand and South Africa. The New Zealand industrial relations system has undergone a period of rapid and fundamental change in the 1980s and the 1990s. Prior to this, the New Zealand system was stable for a half century (Bray and Hayworth 1993) and was characterized by compulsory interest arbitration and extension of "blanket" coverage throughout the industry through a system of industrial tribunals, and high union density (48\%) sustained by compulsory unionism (union shop provisions). This form of industrial relations was complemented and supported by an economic strategy which focused on the export of primary products such as meat, wool, and fruits, coupled with a high degree of import substitution industrialization with protections for local industry. Since the 1970 s, however, there has been a steady decline in both agricultural and manufacturing exports (due to international 
competition), resulting in a steady decline in real wages.

The response in the mid 1980s was a radical deregulation of the New Zealand economy, making it more outward oriented and removing all protective tariffs, price controls, industrial licensing and import licensing, coupled with extensive privatization of state owned industries. As part of this deregulation, there were fundamental reforms in industrial relations legislation. First, the government tried to make the industrial relations system adapt to the changed economic conditions, by encouraging industry-level bargaining councils (from its previously more centralized approach), with concomitant changes in union structure. However, in 1991, the Employment Contracts Act completely dismantled the previous industrial relations system, allowing for individual contracts, removing the compulsory unionism (union shop clause) and blanket coverage of the industry. The law also did not impose a duty to bargain on the employer, while making allowances for both individual and collective contracts. In addition, the compulsory arbitration system through industrial tribunals (a cornerstone of New Zealand's IR system for the last 50 or so years) was dismantled and replaced with private arbitration and mediation. As Hince and Vranken (1991) note, all statutory protections given to trade unions have in effect been repealed and all dispute settlement procedures have been abolished. These changes very strongly suggest discontinuous transformation.

The primary feature of South African industrial relations prior to the lifting of the apartheid regime was duality: white workers had collective bargaining rights and well established procedures that were not extended to black workers. Over the years, the development of the colonial-era slavery system and the deepening of the apartheid system post-independence resulted in, as Webster(1997) notes, a culture of informal workplace resistance by black workers that 
persisted for decades. Although in 1980 the recommendations of the Wiehahn Commission to extend collective bargaining rights to black workers was designed to channel black conflict away from the political sphere to more industrial or business unionism, the legacy of informal workplace resistance built up over decades ensured that the workplace was one of the key centers of resistance to the apartheid system during the 1980s.

After the election of the new ANC dominated Government of National Unity in 1994, a process of reconstruction and development in South Africa began. Reforming industrial relations was particularly crucial, and in 1996 a new labor relations law took effect. The primary features of this law, and thus, the key building blocks of a new system of industrial relations, are the following: the provision of bargaining councils in different industries, the extension of collective bargaining rights to all, and a complete overhaul of the dispute settlement machinery with an accent on mediation for interest disputes and arbitration for some rights disputes, focused heavily on speedy resolution without litigation. Further, they have established a system of bargained corporatism (Baskin 1993), comprised of four actors: government, labor, employers, and the community at large, to create a social and economic contract that focuses on the development of South Africa.

We argue that these three cases are consistent with the description of fundamental change provided by the biological analogies discussed above. In all three cases, there has been transformation, i.e. a reconsideration of “deep structure,” or the network of fundamental and interdependent choices (often implicit) that determine the basic configuration of the system. In addition, the change has been rapid relative to the past, and has involved a period of widespread experimentation, which is suggestive of punctuation or "discontinuous transformation." 
In the case of Sweden, the crisis of the 1980s forced several key actors to reexamine the basic assumptions and choices previously made about the collective bargaining system. Some of the key interdependent choices underlying the previous system were the decisions by employers to pursue the maintenance of industrial peace and predictable wage outcomes, by the government to pursue macroeconomic stability, and by the unions to pursue wage equalization. These choices influenced the design of the collective bargaining model, through a configuration of centralized bargaining via a few bargaining cartels from the 1950s to the 1980s. In the 1980s, faced with increasingly differentiated economic environments, some employers and unions began to reconsider the deep structure, resulting in a period of rapid and revolutionary change. And, since the breakdown in centralized bargaining in the middle of the 1980s, there has been a period of increased speciation and experimentation, where there are more differentiated approaches in different industries, a significant degree of decentralization, and also, attempts by some of the parties to create a new vision and consequent norm for collective bargaining, which has not yet been accepted by all parties. Thus, the Swedish case is consistent with the punctuated equilibrium theory; and, as the system does not yet seem to have emerged from its period of disequilibrium, we should expect to see more experimentation in the next few bargaining rounds (as in the 1993 and 1995 rounds) before the Swedish system settles into a new equilibrium.

In New Zealand as well, there has been a reconsideration of the deep structure. The belief that collective bargaining would benefit all workers and employers under an economic development regime of agricultural exports and import substitution industrialization was the basis for New Zealand's post-war industrial relations configuration. These basic beliefs resulted in an industrial relations system configuration centered around three key pillars: centralized 
bargaining, compulsory union membership, and the industrial tribunal system that automatically extended collective bargaining agreements to the whole industry (blanket coverage). And, as predicted by the punctuated equilibrium perspective, this system was in equilibrium for a significant period of time. The 1980s was a period of revolution, where there were rapid changes in industrial relations, with initial attempts to tinker with the configuration (towards industrial bargaining councils) and later action to completely dismantle the system, reflecting the fact that the essential ideas on which the system was based (which might be termed "egalitarian") were being reconsidered and replaced with a more decentralized, "free market" orientation. Clearly, the post 1991 industrial relations system in New Zealand represents a sea change from the past, and there have been differences across firms in terms of process, structure and outcomes of industrial relations, suggesting both rapid change relative to the past and increased speciation.

The South African case is also consistent with the punctuated equilibrium framework, with one difference. Here the largest actor in industrial relations (black workers) did not have any explicit or implicit assumptions or choices about the configuration of the previous system, i.e. they were not a willing party to it. Hence, although the apartheid era industrial relations system in South Africa was stable (i.e. in equilibrium for a long period), it was built on a foundation that became irrelevant with the change in national political structure: the assumption that black workers should be subjugated, which was a choice of the white government, employers, and some white unions. From 1980 to 1994, with the extension of collective bargaining rights for black workers, there was experimentation with different approaches, but little reconsideration of the previous deep structure. Only after 1994 has there been an attempt to evolve a new system, which involves the development of a new deep structure, one that we would characterize as involving the 
desire to promote equality and economic and social development. However, given its recent nature, it is particularly difficult to say much that is definitive at this point about the extent of experimentation during the emergent transformatory period.

Thus, at least at this level of simplification of these complicated cases, we can identify changes in some of the key components of the deep structure, and label the three cases as “discontinuous transformations." In each of these three cases the parties have questioned the deep structure underlying the basic configuration of the industrial relations system. And, in all three cases, change has been rapid relative to past change in the given system, and there have been increases in speciation and diversity of industrial relations structures and practices in Sweden and New Zealand in particular.

While the recent events in Sweden, New Zealand, and South Africa represent fairly uncontroversial examples of discontinuous breaks from the past, we would like to consider a more controversial case: the development of the "New Deal Labor Policy" in the United States in the 1930s and 1940s. ${ }^{9}$ We attempt here to give a brief narrative account of the development of the New Deal System that stresses points of consistency with the punctuated equilibrium theory. During the 1930s, arguably, the fundamental social choices (or "deep structure") underlying the United States industrial relations system were brought under serious consideration: would unions be formally sanctioned by law? What would the basic mechanisms be for certifying a union and for conducting labor-management relations? Even more, how, exactly, would a union be defined, and how would the workplace be governed?

\footnotetext{
${ }^{9}$ Bacharach and Shedd(1996) also provide an account of the development of industrial unionism in the United States, concentrating on a longer historical period, to illustrate their arguments regarding the sociology of institutional change. We view our approaches as complementary: we approach a similar question from different
} 
Piore and Sabel (1984) argue that "the Depression had called into question the viability of capitalism" (p. 99), suggesting that the severe and inexplicable (given existing theoretical constructs) economic crisis is what placed the deep structure of the democratic-capitalist system in question. Harris (1985) argues that this was "probably the only set of circumstances when American public policy could have taken such a dramatic deviation from its past courses. Only the collapse and chronic stagnation of the economy, the desperate search for answers and palliatives, the massive turnover of state and federal politicians, the partial 'revolution' in the balance and social bases of the two main parties' support, and the accompanying erosion of the political influence of the business community, could have created an opportunity for something like the Wagner Act" (p.183). These authors, then, suggest that the depression can be conceptualized as a "revolutionary period" of reconsideration of the deep structure of industrial relations (and democratic capitalism more generally), in the terms of the punctuated equilibrium theory.

The system that resulted was not extremely pro-labor by European standards; in fact, it was more rule-driven. But, it was a radical change from the existing system in the United States, and represented a transition from industrial relations based on raw expression of power, with minimal formal labor rights, to a highly regulated system with both formal and informal rules regulating the union representation process and specifying a relatively high number of contingencies in the unionized workplace. ${ }^{10}$ Once these issues were settled over the course of the

disciplinary perspectives, and illuminate somewhat different aspects of the complex phenomenon of social system transformation.

${ }^{10}$ Freeman (1997) argues that the New Deal labor legislation was essentially irrelevant to the increase in union membership, which he argues was driven by an "endogenous social process" instead. Whatever the causality (whether the legislation drove social and institutional change or vice-versa), we argue here that the Wagner Act and accompanying changes in formal rules and informal practice amounted to a transformation of the form of regulation 
nineteen thirties and nineteen forties, given the socio-economic conditions of the time, they were no longer contested; while there were continuous and minor adjustments, the system had entered a period of stability during which the "deep structure" underlying the New Deal Industrial Relations System - reflected in legal and social recognition of the basic legitimacy of unions was taken for granted. Thus, we argue that the nineteen thirties and nineteen forties can be conceptualized as a "revolutionary period" of rapid and discontinuous questioning and change in the basic assumptions underlying United States industrial relations, while the later post-war period can be conceptualized as an "equilibrium period" of institutionalization and entrenchment of the policies, reflecting the establishment of the new deep structure of industrial relations whereby unions were accepted as the legitimate and (and even preferred) means for regulating the workplace.

However, once the socio-economic conditions (such as intense competition arising out of both globalization and changing world markets) evolved so as to no longer be compatible with the operation of this system and, moreover, the system began to show internal systemic "wear and tear" (e.g. employers learned how to and/or chose to fully exploit their advantages under the certification election procedures, the excesses of unions turned public opinion in a noncollectivist direction, etc.), the system's viability was once again called into question. It has been recently argued that the United States industrial relations system has again moved into a period of transformatory change, where the fundamentals of labor policy (likely a reflection of the "deep structure" of the industrial relations system) are being increasingly debated in both academic and policy circles (see, for example, Strauss (1995) and the Commission on the Future of Worker-

of the United States workplace and collective bargaining more generally, with the features of job-control unionism 
Management Relations (1994)). Many argue that industrial relations practice in the United States is also undergoing a period of rapid change and widespread experimentation and "speciation," with the diffusion of new practices such as team based production, quality circles, worker participation, and labor-management collaboration, all practices that have been construed to reflect a fundamental and discontinuous change from the recent history of workplace industrial relations in the United States (e.g. Kochan, Katz, and McKersie(1986)). But, a key question is whether the nineteen eighties have seen a reconsideration of the deep structure of industrial relations (and the larger socio-economic system) to the same profound degree as was experienced in the nineteen thirties.

We also want to be clear that, in our view, the definition of industrial relations “transformation” is not necessarily synonymous with "punctuated equilibrium.” The German system, as discussed above, seems to have recently evolved more gradually and continuously away from its previously more centralized incarnation. The key question in this case would seem to be whether the deep structure of the German system has come under serious consideration. Does the gradual shift in the emphasis of the works councils reflect a fundamental reconsideration of basic societal assumptions? If so, as many experts argue, then the biological analogies suggest that the recent German case should be labeled as an "incremental” or "adaptive” transformation, rather than a punctuated equilibrium transformation.

\section{Conclusions}

In recent years researchers have turned their attention to how and why entire industrial

(and, more importantly, the assumptions underlying them) constituting at least as important a break from the past as 
relations systems evolve, and it has been in the context of the "transformation debate." We argue that the evolutionary biology and punctuated equilibrium frameworks help to bring some clarity to this debate by providing, at a theoretical level, some guidance for determining whether there has been a transformation, as well as the type of transformation, in a given industrial relations system.

The essence of any transformation, whether discontinuous or incremental, is the existence of serious reconsideration of the network of fundamental, interdependent choices that determine the basic configuration into which an industrial relations system's units are organized (or the “deep structure”). The key defining features of a “discontinuous” or “punctuated equilibrium” (as opposed to "incremental” or "adaptive”) transformation in terms of the punctuated equilibrium theory are the speed of change (relative to previous periods of "stability" in a given system) and the occurrence of significant experimentation and increases in speciation and diversity.

However, we also note that distinguishing between "transformation” and "nonfundamental change” in industrial relations systems is very difficult, particularly in making the judgment as to what exactly constitutes “deep structure” and whether it is seriously under consideration. For example, under what circumstances does "significant decentralization" of industrial relations process and outcomes indicate a reconsideration of basic assumptions regarding the system? We have mostly identified country-specific indicators of deep structure in this paper. One key question for future research involves the possible existence of more universal or generic constituents of deep structure. Some possible universal constituents of “deep structure” of industrial relations, in our view, might include attitudes toward and definitions of property rights in the workplace, employer/employee relative status, and the nature of exchange in the labor 
market. Changes in the essence of employer, union, and government strategies and structures may also indicate (if not constitute) changes in deep structure. We expect, however, that further analysis would reveal a wider and more controversial range of constituent elements.

We have identified two types of transformation: incremental (or adaptive) and discontinuous (or punctuated equilibrium). Given the wide diversity in experience of industrial relations systems in the twentieth century, perhaps the most interesting question of all is: Why do some systems adapt, while others remain rigid until they encounter discontinuous change? A compelling and intuitive answer to this question is that Tayloristic, job-control based systems are inherently rigid and must therefore snap and change in punctuations, while corporatist systems are inherently more flexible and therefore can more gradually change to adapt to external circumstances that are no longer consistent with the internal logic of the existing system (see Locke, Kochan, and Piore (1995, p. 366) for the argument that Tayloristic systems have “experienced the greatest pressures to transform their work organization arrangements”).

The Swedish example, however, suggests that this is not always the case: most everyone, including Golden, Wallerstein, and Lange (1997), seem to agree both that Sweden is a corporatist system and that recent developments there amount to discontinuous change. Is the Swedish case an anomaly, or does this counter-example suggest a different set of causes (beyond the extent of Tayloristic job-control) for the type of change experienced by a given system? ${ }^{11}$ For now, we

\footnotetext{
${ }^{11}$ Thelen (1994), invoking Soskice (1990), describes the difference between Germany and Sweden as follows: "German employers had greater incentives to seek compromise within the existing framework of bargaining because that framework already provided more flexibility through coordinated industry level rather than peak level bargaining and because the character of relations between central and local bargaining within Germany's 'dual system' facilitated rather than impeded negotiated compromise between unions and employers over issues of flexibility.... In Sweden, by contrast, centralized solidaristic wage bargaining had evolved in such a way that it inhibited rather than facilitated compromise between unions and employers on the issue of flexibility and exacerbated the problems with skilled workers... Centralized bargaining arrangements (in Sweden) thus constrained
} 
leave this as an unresolved (but fundamental) research question raised by our analysis: why is it that some systems “adapt” while others experience discontinuous change?

Related to these issues regarding the adaptability of Tayloristic systems is the question of whether the various national industrial relations systems are changing in a similar direction. Is the global economy generating a common set of external imperatives that are driving the different systems toward a single model (most obviously, a model that involves decentralization toward the workplace)? If so, is the extent of transformation in each system a function of the distance from a common ideal toward which the systems are evolving? And, does it even make sense to think in terms of "national models," or are we genuinely experiencing the emergence of a "global economy” with a "global industrial relations system”? ${ }^{12}$

Thus, we pose as issues for future research the extent and determinants of "incremental” versus “discontinuous” change in national industrial relations systems in recent years, as well as the extent to which systemic-internal factors, such as demographics and politics, versus external environmental factors, such as the alleged "globalization” of the world economy, have driven the change, and whether the change in the various systems is in a similar direction. Obviously, these questions in particular will require both time and extensive analysis before firm consensus conclusions can be reached.

We argue that these difficult questions will have to be acknowledged and addressed in order to move forward toward a meaningful resolution of the "transformation debate.” What we have attempted to do here is more modest: to provide the beginnings of a framework for defining

unions' ability to negotiate more flexible wages and generated strong incentives for employers to dismantle the institutions that produced and reproduced these effects" (pp. 121-122).

${ }^{12}$ To complicate matters further, some argue that it makes more sense to think in terms of regional economic and industrial relations systems, rather than national or global systems. See Locke(1995). 
industrial relations system transformation and for distinguishing incremental from discontinuous transformation in those systems. 


\section{References}

Abraham, Katherine G. and Susan N. Houseman. (1995). “Earnings Inequality in Germany.” In Freeman, Richard and Lawrence Katz, eds., Differences and Changes in Wage Structures. University of Chicago Press for NBER, pp. 371-404.

Armingeon, Klaus. 1994. Staat und Arbeitsbeziehungen: ein internationaler Vergleich. Opladen, Westdeutscher Verlag.

Abernathy, William J. and James M Utterback. 1982. Patterns of Industrial Innovation. In M. Tushman and W. Moore (Eds)., Readings in the Management of Innovation 97-108. Boston, Mass: Pitman Publishing.

Bacharach, Samuel B. and Joseph B. Shedd. 1996. "Institutional Change: Rules of Practice, Logics of Transactions, and Regimes in the Case of the Emergence of Industrial Unionism.” Working Paper.

Baethge, Martin and Harald Wolf. 1995. "Continuity and Change in the 'German Model' of Industrial Relations.” In Locke, Richard, Thomas Kochan, and Michael Piore, eds., Employment Relations in a Changing World Economy. Cambridge: MIT Press. Pp. 231-262.

Baskin J. 1993. "Corporatism: Some Obstacles facing the South African Labour Movement." Research report No. 30. Johannesburg: Center for Policy Studies.

Boyer, Robert. 1990. The Regulation School: A Critical Introduction. Columbia University Press.

Bray, Mark and Nigel Hayworth. 1993. Economic Restructuring and Industrial Relations in Australia and New Zealand. Sydney: Australian Centre for Industrial Relations Research and Teaching, Monograph No. 8.

Collier, Ruth B. and David Collier. 1991. Shaping the Political Arena. Princeton: Princeton University Press.

Commission on the Future of Worker-Management Relations. 1994. Report and Recommendations. United States Departments of Labor and Commerce.

Cook, Maria. 1996. "Mexican Industrial Relations in Transition: What's New Since NAFTA?” In Voos, Paula B, ed., Proceedings of the Forty-Eighth Annual Meeting. Madison: Industrial Relations Research Association, pp. 348-356.

Crouch, Colin. 1993. Industrial Relations and European State Transitions. Oxford University Press. 
Darwin, Charles. 1859. The Origin of Species. New York: the Modern Library.

David, Paul A. 1985. "Clio and the Economics of QWERTY.” American Economic Review Vol. 75, No. 2, pp. 332-37.

Davis, Stephen J. 1992. “Cross-Country Patterns of Change in Relative Wages.” NBER working paper no. 4085. Cambridge, Mass: National Bureau of Economic Research.

Dunlop, John. 1993. Industrial Relations Systems: Revised Edition. Cambridge: Harvard Business School Press.

Eldredge, N., and S. Gould, 1972. "Punctuated Equilibria: An Alternative to Phyletic Gradualism." In T.J. Schopf (Ed.), Models in Paleobiology: 82-115. San Rancisco: Freeman, Cooper \& Co.

Elvander, Nils. 1997. "The Role of the State in Industrial Relations in Sweden.” In Brown, Josephine (ed), The Role of the State in Industrial Relations, Volume 3 of the Official Proceedings of the Fifth IIRA European Regional Conference, Dublin Ireland, 26-29 August 1997. Dublin: Oak Tree Press.

Freeman, Richard. 1997. "Spurts in Union Growth: Defining Moments and Social Processes." NBER Working Paper \#6012.

Freeman, Richard and Lawrence Katz. 1995. Differences and Changes in Wage Structures. University of Chicago Press for NBER.

Frenkel, Stephen 1988. "Containing Dualism through Corporatism: Changes in Contemporary Industrial Relations in Australia." Bulletin of Comparative Industrial Relations, Special Issue on Economic Restructuring and Industrial Relations. Bulletin no. 20. 1990 Pages 113-145.

Gersick, Connie. 1988. "Time and Transition in Workteams." Academy of Management Journal.

Gersick, Connie. 1991. "Revolutionary Change Theories: A Multilevel Exploration of the Punctuated Equilibrium Paradigm." Academy of Management Review.

Golden, Miriam A. and Michael Wallerstein. Reinterpreting Postwar Industrial Relations: Comparative Data on Advanced Industrial Societies. Manuscript, May 1996.

Golden, Miriam A., Michael Wallerstein, and Peter Lange. 1997. "Unions, Employer Associations, and Wage-Setting Institutions in Northern and Central Europe, 1950-1992," ILR Review, Vol. 50, No. 3 (April) pp. 379-401.

Gordon, David M., Richard Edwards, and Michael Reich. 1982. Segmented Work, Divided Workers. Cambridge: Cambridge University Press. 
Gould, Stephen. 1991. Bully for Brontosaurus. London: Hutchinson Radius.

Hannan, Michael T. and John Freeman. 1989. Organizational Ecology. Harvard University Press.

Harris, Howell. "The Snares of Liberalism? Politicians, Bureaucrats, and the Shaping of Federal Labor Relations Policy in the United States, ca. 1915-47.” In Steven Tolliday and Jonathan Zeitlin, ed., Shop Floor Bargaining and the State.

Hince, Kevin and Vranken, Martin. 1991. “A Controversial Reform of New Zealand Labor Law: The Employment Contracts Act of 1991.” International Labor Review. Vol. 130. no. 4, pp. 475-493.

Hofstader, Richard. 1945. Social Darwinism in American Thought. Philadelphia: University of Pennsylvania Press.

Hyman, Richard. 1994. "Industrial Relations in Western Europe: An Era of Ambiguity?" Industrial Relations, Vol. 33. No. 1, pp. 1-24.

Jones, Derek C., "Successor Unions in Transitional Economies: Evidence from St. Petersburg," ILR Review, Vol. 49, No. 1, October 1995, pp. 39-57.

Jurgens, Ulrich, Larissa Klinzing, and Lowell Turner. 1993. "The Transformation of Industrial Relations in Eastern Germany,” ILR Review, Vol. 46, No. 2 (January) pp. 229-244.

Katz, Harry C. 1993. "The Decentralization of Collective Bargaining: A Literature Review and Comparative Analysis.” Industrial and Labor Relations Review, Vol 47, no. 1 (October).

Katz, Harry, Sarosh Kuruvilla and Lowell Turner. 1992. "Trade Unions and Collective Bargaining.” In Impediments to Competitive Labor Markets: An Overview of Policy and Research Issues. The World Bank, PHREE.

Koch, Karl. 1995. “The German Works Council and Collective Bargaining Development Since Unification.” German Politics, Vol. 4, No. 3 (December 1995), pp. 145-155.

Kochan, T.A., Katz, Harry C. and McKersie, Robert. 1986. The Transformation of American Industrial Relations. Basic Books.

Kuhn, Thomas. 1962. The Structure of Scientific Revolutions. Chicago: University of Chicago Press.

Kuruvilla, Sarosh. 1996. "The Relationship Between Economic Development Strategies and Industrial Relations: India, Malaysia, Singapore and the Philippines." Industrial and Labor Relations Review. Vol. 49. No. 4 (July). 
Kuruvilla, Sarosh and Christopher Erickson. 1995. "Critical Junctures in the Transformation of Industrial Relations Systems: A Comparative Study of Nine Countries.” Working Paper.

Kuruvilla, Sarosh, Harry Katz, and Lowell Turner. 1994. "Industrial Relations Reform in South Korea.” Korea Labor Institute: Seoul.

Levinson, D.J. 1978. The Seasons of a Man's Life. New York: Knopf.

Locke, Richard. 1995. Remaking the Italian Economy. Ithaca: Cornell University Press.

Locke, Richard, Thomas Kochan, and Michael Piore. 1995. "Conclusion: The Transformation of Industrial Relations? A Cross-National Review of the Evidence.” In Locke, Richard, Thomas Kochan, and Michael Piore, eds., Employment Relations in a Changing World Economy. Cambridge: MIT Press, pp. 359-384.

Miller, D. and Freisan, P. 1984. Organizations: A Quantum View. Englewood Cliffs: New Jersey: Prentice Hall.

The New York Times. 6/5/97. “German Union Gives Opening For Wage Cuts.”

Piore, Michael J. and Sabel, Charles, F. 1984. The Second Industrial Divide: Possibilities for Prosperity. New York: Basic Books.

Ryner, Magnus. 1994. “Assessing the SAP’s Economic Policy in the 1980s: The Third Way, The Swedish Model, and the Transition from Fordism to Post-Fordism." Economic and Industrial Democracy, Vol. 15, pp. 385-428.

Soskice, David. 1990. "Reinterpreting Corporatism and Explaining Unemployment: Coordinated and Non-coordinated Market Economies.” In Brunetta, Renato and Carlo Dell'Aringa, ed., Labour Relations and Economic Performance (London: Macmillan, 1990).

Strauss, George. 1995. "Is the New Deal System Collapsing? With What Might It Be Replaced?" Industrial Relations, Vol. 34, No. 3 (July 1995), pp. 329-349.

Streeck, Wolfgang. 1988. “Industrial Relations in West Germany, 1980-1987.” Labour, Vol. 2, No. 3, pp. 3-44.

Swenson, Peter. 1989. Fair Shares: Unions, Pay and Politics in Sweden and West Germany. Ithaca: Cornell University Press.

Thelen, Kathleen. 1994. "Beyond Corporatism: Toward a New Framework for the Study of Labor in Advanced Capitalism.” Comparative Politics, October. 
Turner, Lowell. 1991. Democracy at Work: Changing World Markets and the Future of Labor Unions. Ithaca: Cornell University Press.

Webster, Eddie. 1997. “Confronting the Past: Changing Industrial relations in South Africa.” In Kuruvilla, S. and S. Bacharach, and B. Mundell, ed., Research in the Sociology of Organizations. (JAI Press, forthcoming). 


\section{Table 1: Studies of Industrial Relations System Transformations}

Study

Kochan, Katz, and

McKersie (1986)

Katz (1993)

Locke, Kochan and

Piore (1995)

Armingeon (1994)

Kuruvilla (1996)

Transformation

Golden, Wallerstein and No Transformation Lange (1997)

$\underline{\text { Claim }}$

Transformation

Transformation

Transformation

Transformation 
Crouch (1993)

Hyman (1994)

Dunlop (1993)

Freeman and Katz (1995)
No Transformation

No Transformation

No Transformation
Stability of formal institutional mechanisms

Dimensions of change in management initiative;

Decline of unionism; Deregulation of labor markets;

Decline of national systems

Adaptations in IR due to changing demographic, market, technological and political environment

Mixed evidence regarding increased variation in wage structures 